VORTEX OF CONFLICT 



\section{VORTEX OF CONFLICT}

U.S. Policy Toward Afghanistan, Pakistan, and Iraq

DAN CALDWELL

STANFORD SECURITY STUDIES

An Imprint of Stanford University Press

Stanford, California 
Stanford University Press

Stanford, California

(C) 2011 by the Board of Trustees of the Stanford Leland Junior University. All rights reserved.

No part of this book may be reproduced or transmitted in any form or by any means, electronic or mechanical, including photocopying and recording, or in any information storage or retrieval system without the prior written permission of Stanford University Press.

Library of Congress Cataloging-in-Publication Data

Caldwell, Dan (Dan Edward), author.

Vortex of conflict : U.S. policy toward Afghanistan, Pakistan, and Iraq / Dan Caldwell.

pages. $\mathrm{cm}$.

Includes bibliographical references and index. ISBN 978-0-8047-7665-3 (cloth : alk. paper) ISBN 978-0-8047-7666-o (pbk. : alk. paper)

1. United States-Foreign relations-2001-2009. 2. Afghan War, 2001-. 3. Iraq War, 2003-. 4. War on Terrorism, 2001-2009. 5. United StatesMilitary policy. I. Title.

E902.C34 2011

973.93-dc22

2010045290

Printed in the United States of America on acid-free, archival-quality paper. Typeset at Stanford University Press in 10/14 Minion.

Special discounts for bulk quantities of Stanford Security Studies are available to corporations, professional associations, and other organizations. For details and discount information, contact the special sales department of Stanford University Press.

Tel: (650) 736-1782, Fax: (650) 736-1784 
To those who have served in Afghanistan and Iraq and their families, With appreciation and gratitude 
